ECONOMICS

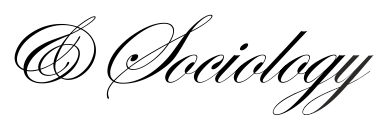

J. Vicente Fruet-Cardozo, Area of Applied Economics

University of Cordoba,

Cordoba, Spain

E-mail:jufruet@uco.es

José R. Millán,

Area of Financial Economics

University of Cordoba,

Cordoba, Spain

E-mail:es1milaj@uco.es

José M. Caridad y Ocerin, Area of Statistics and Econometrics

University of Cordoba,

Cordoba, Spain

E-mail:scjm@uco.es

Jesús C. Perez-Galvez,

Area of Applied Economics

University of Cordoba,

Cordoba, Spain

E-mail:dt1pegaj@uco.es

Received: January, 2019

1st Revision: May, 2019

Accepted: August, 2019

DOI: $10.14254 / 2071-$

789X.2019/12-3/18

JEL Classification: C33, G21, G32
Fruet-Cardozo, J.V., Millán, J.R., Caridad y Ocerin, J.M., \& Perez-Galvez, J.C. (2019). Impact of capital increase on solvency and profitability of Spanish deposit banks. Economics and Sociology, 12(3), 273-290. doi:10.14254/2071-789X.2019/12$3 / 18$

\section{IMPACT OF CAPITAL INCREASE ON SOLVENCY AND PROFITABILITY OF SPANISH DEPOSIT BANKS}

\begin{abstract}
The aim and hypothesis of this article is to demonstrate that capital increases taking place in the Spanish banking system for almost half a century (19712017) led to an increase in both the solvency and the profitability of the system, taking into account the changing situation in the Spanish banking environment in this period. However, it was difficult to homogenise the 1968-70 data with the period studied. Therefore, in addition to analysing ten traditional ratios, a structural equation model (SEM) in path analysis modality was used to validate the results of the effects of the evolution in equity. SEM is widely used in the economic and social sciences to estimate regression models (usually multi-equational) and establish relations between different financial variables and ratios. The estimated model shows a significant global acceptability based on the usual statistical tests and goodness-of-fit measures. The model supports the research hypothesis and the conclusions. The fundamental changes in the Spanish banking system over the last five decades, including the virtual disappearance of the savings bank subsector, has increased the overall solvency of the remaining firms and consolidated their profitability during the crisis years.
\end{abstract}

Keywords: Spanish banks, consolidated financial statements, ratios, equity, net profit, SEM.

\title{
Introduction
}

Substantial changes have occurred in the Spanish banking system over the fifty-year period from 1971 to 2017. The first was the conversion of banks into more generalist business financial entities focused on the commercial and industrial sector. The second was the transformation of numerous local and national banks into international financial holdings, among which two groups clearly stand out. Additionally, the savings bank sector practically 
disappeared following the financial crisis of the last decade. As regards bank management, it has been difficult to obtain reasonable results for shareholders in recent years due to a gradual but permanent decline in the spreads for different investment operations. In this regard, it should be highlighted that the primary purpose of banking systems must be to finance the real economy. That is its essence and its origin. However, this situation has also changed gradually in the last decades. Although the global banking system today proclaims and presents leverage as the financial panacea, the leverage of the system has weakened the banking financial structure. This fragility is particularly notable with the increasingly frequent economic tsunamis. Our study is an attempt to address these issues, which we consider vital today, not only in Spain and in the EU, but throughout the economic world.

In 1971, the Spanish banking system comprised 219 entities: five public banks, 125 private banks, of which 15 were large firms, and 89 savings banks. To give an idea of the importance of savings banks, almost half of the deposits were managed by these financial entities (Calvo, Parejo, Rodríguez, \& Cuervo, 2010; Tamames, 1971). According to the annual report of the Spanish Banking Association for the year 2017 (Asociación Española de Banca, 2016, 2018), the structure of the system changed radically. At that time, there were 59 banks and just two savings banks, whose deposits accounted for only $1.2 \%$ of the total banking system.

The hypothesis of this paper is that the capital increases experienced in the Spanish banking system for 47 years (i.e., from 1971 to 2017) have had a positive impact not only on the system's solvency, but also on its profitability. It is important to mention that from 2009 to 2015 the capital increases were not made with the system's own resources, but with funds from the so-called "bailouts" of Spanish deposit institutions.

To support our hypothesis, in addition to having applied 10 ratios to the consolidated economic and financial statements of that period, we have used a multi-equation econometric model that aims to explain the variability of some profit and results variables. In this way, as a previous stage, the economic and financial ratios were related with variables used in the proposed path analysis model (Hikmet, Lin, \& Mooney, 2011).

Path analysis and structural equations models (SEM) (Elosua, 2011) attempt to confirm the causal associations in directly observable data and between latent variables, respectively, assuming that these existing associations are linear, although there are extensions for non-linear situations. This method allows examining a set of associations between one or more continuous or discrete exogenous variables (Caridad y Ocerín, 2016) by breaking the correlations observed in a system of equations that described his hypotheses relating to causal association. The causal associations between the variables are then represented by a path chart.

The rest of the paper is structured as follows. Section 1 provides a review of the literature. Section 2 presents the methodology, the data collected for the almost five decades considered, the consolidated balance sheet and income statement from the Spanish banking system, as well as their evolution. In section 3, the results are described and explained individually. Section 4 presents the discussions and section 5 concludes.

\section{Literature review}

In relation to our analysis and the association with capital increase and impact on the solvency and profitability of banks, Trujillo (2013) studied commercial and savings banks in Spain for the period 1999-2009. The author found that neither the size of the entity nor growth rates is valid for explaining profitability, although the ratio of capital positively explains the rate of return. Trujillo also analysed the persistence of banks from 65 developed countries, finding evidence of a negative influence on the growth of cost effectiveness, as within a market with strong competition, persistence must be weak in economies where institutional development is more advanced and external governmental mechanisms are strong. Likewise, 
Dietrich, Hess, and Wanzenried (2014) examined how the new capital requirements established in Basel III affect the profitability of central European banks. Goddard, Molyneux, and Wilson (2004) studied the cost effectiveness of the main European banks and found that patrimonial persistence is larger in banks and credit cooperatives than commercial banks.

On the other hand, Hikmet et al. (2011) studied the determinants of corporate leverages in Japan using path analysis. Aymanns, Cáceres, Daniel, and Schumacher (2016) examined the sensitivity of bank funding cost to solvency measures while monitoring other measures of bank fundamentals. Their analysis included two measures of bank funding cost: (a) average funding cost and (b) interbank funding cost, as a proxy of wholesale funding cost. Bassett, Lee, and Spiller (2015) analysed the discussed styles of banking supervision in recent years and estimated changes in them, as well as their influence on the economic scene. Calice (2014) used a panel of annual observations for 198 banks in 19 Middle East and North African countries over the period 2001-2012 in order to develop an early warning system for forecasting bank insolvency based on a multivariate logistic regression framework. Jérômy and Kok (2013) propose that the use of macro stress tests to assess bank solvency has developed rapidly over the past few years. The authors underlined that this development was reinforced by the financial crisis, which resulted in substantial losses for banks and created general uncertainty about the banking sector's loss-bearing capacity. Jobst, Ong, and Schmieder (2013) recognised that International Monetary Fund staff have developed more robust stress testing methods and models and adopted a more coherent and consistent approach after the latest global economic crisis. According to Dombret and Lucius (2013), after the latest crisis, financial stability encompasses more than the sum of the individual risks that exist in a financial system. Borio and Drehmann (2009) reviewed the available measurement methodologies and pointed out several weaknesses of macro stress tests, arguing that they can lull policymakers into a false sense of security. Baker and Wurgler (2002) used market-to-book ratios to investigate the impact of market timing on capital structure and found that firms with lower leverage tend to raise funds when their market-to-book ratios are high. In contrast, highly leveraged firms tend to raise funds when their valuation is low. A firm's current capital structure is therefore partially the cumulative outcome of past attempts to time the market.

In a comparative investigation of Japanese and US corporate control, Morck and Nakamura (1999) found significant differences between US and Japanese firms in the relations between ownership structure and firms' performance. Major banks in particular play a key ownership role in Japan. In contrast, Fohlin (1998) found that relationship banking in Germany did not provide consistent lessening of the sensitivity of corporate liquidity to firms' cash flow in the banking period 1903-1913. Likewise, Kang and Stulz (1996) showed that the 1980s liberalisation in Japanese finance and banking caused abnormal returns in Japanese firms closer to those of US firms. In their international comparison of capital structure, Rajan and Zingales (1995) argued that the structure is determined by growth, capital intensity or tangibility of assets, profitability, and size.

Many studies on capital structure have found evidence that firms try to maintain a target capital structure. Over time, debt ratios are associated with firms' characteristics, such as size, market valuation, high levels of fixed or tangible assets, and the marginal tax rate. For instance, Fama and French (2002) determined that more profitable firms are less leveraged and, as the pecking order model predicts, short term variation in investment and earnings is mostly absorbed by debt.

In relation to the methodology used in the analysis, Duncan (1966) investigated path analysis as a useful tool in making explicit the rationale of conventional regression calculation. Elosua (2011) proposed a model in the framework of SEM to assess preferences among quality of life dimensions for the elderly. Badri, Davis, and Davis (2000) studied the business environment, operations strategy and performance of Singapore's manufacturers and applied a 
path analytic framework to study the effects of the environment on the choice of operations strategy and performance for a sample of United Arab Emirates manufacturers. Likewise, Badri and Alshare (2008) tested a model for the measurement of the business value of e-governments. Path Analysis was also used to test these hypotheses. The classical literature on this topic includes the seminal work of Bagozzi and Heatherton (1994), who proposed a framework for representing personality constructs at four levels of abstraction using latent variables. Browne and Cudeck (1993) considered two types of error involved in fitting a model: the first one was error of approximation and the second one was overall error which involved the fit of the model. According to Bentler (1990), coefficient yield new normed (CFI) and non-normed fit indexes (NFI) are frequently used as adjuncts to chi-square statistics for evaluating the fit of a structural model. Similarly, Bollen (1989) described the use of structural equations in different sectors. Finally, in relation to the identifiability (estimability) of multi-equation models, Caridad y Ocerín (2016) argued that the path analysis method as a way to approach the representation of a multiequational model needs to have all its equations identified in order to estimate all the equations and produce the corresponding interpretation. If only part of the relations can be identified, only these can be interpreted once estimated.

\section{Methodological approach}

\subsection{Overview}

SEM is an extension of the general linear model, while path analysis is a particular case of SEM (Caridad y Ocerín, 2016). SEM allows the estimation of equations and the analysis of the existing causal relationships among several variables. Path analysis is used with observable numerical variables and, in addition to the model specification, can be used to decompose the correlation coefficients among the variables in several parts to represent the direct, indirect, and non-causal effects. In general SEM models, latent variables models are specified jointly with factor analysis models using observable variables related to the latent part of the construct (Bollen, 1989).

In what follows, a summary of SEM is provided. Several different types of variables are identified according to their measurement or the role they perform in the model, which include the following:

Latent variables (Bollen, 1989), which are also known as constructs, are factors or variables that are not observable. These variables are usually the object of interest for analysing abstract concepts that can be indirectly observed through their effects on the observed indicators or variables. The only latent variables in path analysis are related to the residual terms in each equation (Hikmet et al., 2011; Duncan, 1966).

Observable variables, also known as measurement or indicator variables, are variables with available data. They can be classified into three types as follows.

- Exogenous variables are independent variables, that is, they affect other variables while they are not impacted by any of them. These variables can be identified on diagrams as they have no arrows pointing at them.

- Endogenous variables are dependent variables which are impacted by other variables. On diagrams, these variables have arrows coming in. They are also impacted by perturbation or error terms.

- Error variables are latent variables that take into account all the sources of variation that are not explicitly considered in the model and are non-significant individually, but have an observable impact as a group of variation causes. 


\subsection{Sample data}

The sample of banks, including savings banks and credit institutions in the Spanish financial sector, were selected from database of the Bank of Spain, which is responsible for regulating the banking sector. The consolidated balance sheets and the profit and loss charts of the Spanish deposit institutions correspond to the period 1971 to 2017, that is, a 47-year interval (Association, 2016, 2018). Ten financial ratios were obtained from the database with the general aim of analysing the effect of the main variables in the balance sheet on profits or solvency related information (Rose, 2002). A summary of economic and financial information is provided in tables 2, 3, and 4. A path analysis approach is used to determine the causal relationships among the variables.

Table 1 shows the originally selected ratios and type of variable they represent.

Table 1. Variables and ratios originally selected for the analysis

\begin{tabular}{clcc}
\hline Acronym & & Ratios & Type of variable \\
\hline X1 & Capital Increase & & \\
X2 & Capital/Assets & Indebtedness & \\
X3 & Equity/Assets & Indebtedness & Exogenous \\
X4 & Liabilities/Assets & Indebtedness & \\
X5 & Administrative Costs/Operating Income & Efficiency & \\
X6 & Intermediation Margin & Efficiency & \\
Y1 & Net benefit & Profitability & \\
Y2 & ROE & Profitability & Endogenous \\
Y3 & ROA & Profitability & \\
Y4 & Equity/Liabilities & Solvency & \\
e1 & & & \\
e2 & & & Error variables \\
e3 & & & \\
e4 & & & \\
\hline
\end{tabular}

Source: Own elaboration.

\subsection{Comments on the consolidated balance sheet}

It is important to note that the figures in the financial statements from 1971 to 2001 originally appeared in pesetas, the Spanish currency prior to the euro. For the period 2002 to 2017 all figures are shown in euros. The INE (the National Statistics Institute of Spain) webpage was the source used for the conversions from current to constant figures.

a. Assets: As can be seen in Table 2, for the period analysed, the system's assets grew in current terms by $15,130.20 \%$ (i.e., 151 times) from $16,854,916$ million euros in 1971 to $2,550,188.1$ million in 2017 (in constant terms, 750,6\%). As shown, in 1971 other resident sections (ORS) was the main investment in the balance, accounting for $56.7 \%$ of total assets, that is, 9,560.5 million/16,854.9 million euros. But this item decreased progressively and in 2017 was $47.0 \%$, that is, $1,199106,319$ million/2,550,188,101 million euros. Moreover, in 1971, commercial loans were the major item within ORS credits; however, from the mid-1970s, mortgage loans began to establish themselves as the major item in the assets. 
INTERDISCIPLINARY APPROACH TO ECONOMICS AND SOCIOLOGY

Table 2. System's consolidated assets - Dec. 31, 1971 to Dec. 31, 2017 (000 euros)

\begin{tabular}{|c|c|c|c|c|c|c|}
\hline ASSETS & 1971 & 1980 & 1990 & 2000 & 2010 & 2017 \\
\hline CREDITS & $12,842,986$ & $80,586,823$ & $295,294,231$ & $779,067,305$ & $2,268,404,055$ & $1,680,260,216$ \\
\hline Credit system & $2,574,267$ & $14,675,550$ & $91,515,908$ & $129,633,889$ & $188,441,535$ & $214,793,432$ \\
\hline Public Administrations & 10,037 & 121,002 & $8,681,404$ & $28,811,973$ & $74,491,997$ & $74,339,530$ \\
\hline ORS & $9,560,510$ & $57,533,272$ & $175,103,242$ & $526,632,753$ & $1,782,291,283$ & $1,199,106,319$ \\
\hline External sector & 698,172 & $8,256,999$ & $19,993,677$ & $93,988,690$ & $223,179,240$ & $192,020,935$ \\
\hline VALUES OTHER THAN SHARES and & 0 & 13303499 & 45751989 & 127638286 & 1449 & 30468 \\
\hline Residents in Spain & 0 & $13,295,686$ & $44,758,498$ & $102,673,752$ & $313,915,760$ & $247,453,222$ \\
\hline Residents in the rest of the world & 0 & 7,813 & 993,491 & $24,964,534$ & $63,885,689$ & $71,077,246$ \\
\hline SHARES AND PARTICIPATIONS & 542,720 & $2,145,036$ & $9,839,867$ & $75,293,682$ & $180,188,964$ & $258,742,503$ \\
\hline Residents in Spain & 531,938 & $2,011,287$ & $8,203,377$ & $48,175,524$ & $102,877,982$ & $145,388,331$ \\
\hline External sector & 10,782 & 133,749 & $1,636,490$ & $27,118,158$ & $77,310,982$ & $113,354,172$ \\
\hline OTHERS NOT SECTORISED & $3,469,210$ & 534,726 & $26,379,154$ & $5,850,083$ & $292,862,590$ & $292,654,914$ \\
\hline Cash & 179,180 & 154,112 & $2,799,027$ & $5,386,264$ & $7,882,548$ & $8,071,726$ \\
\hline Others & $3,290,030$ & 380,614 & $23,580,127$ & 463,819 & $284,980,042$ & $284,583,188$ \\
\hline TOTAL ASSETS & $16,854,916$ & $96,570,084$ & $377,265,241$ & $987,849,356$ & $3,119,257,058$ & $2,550,188,101$ \\
\hline
\end{tabular}

Source: Own elaboration and consolidation data based on Bank of Spain data.

As shown in Figure 1, account values other than shares and participations was the second most important item, followed by other non-sectorised.

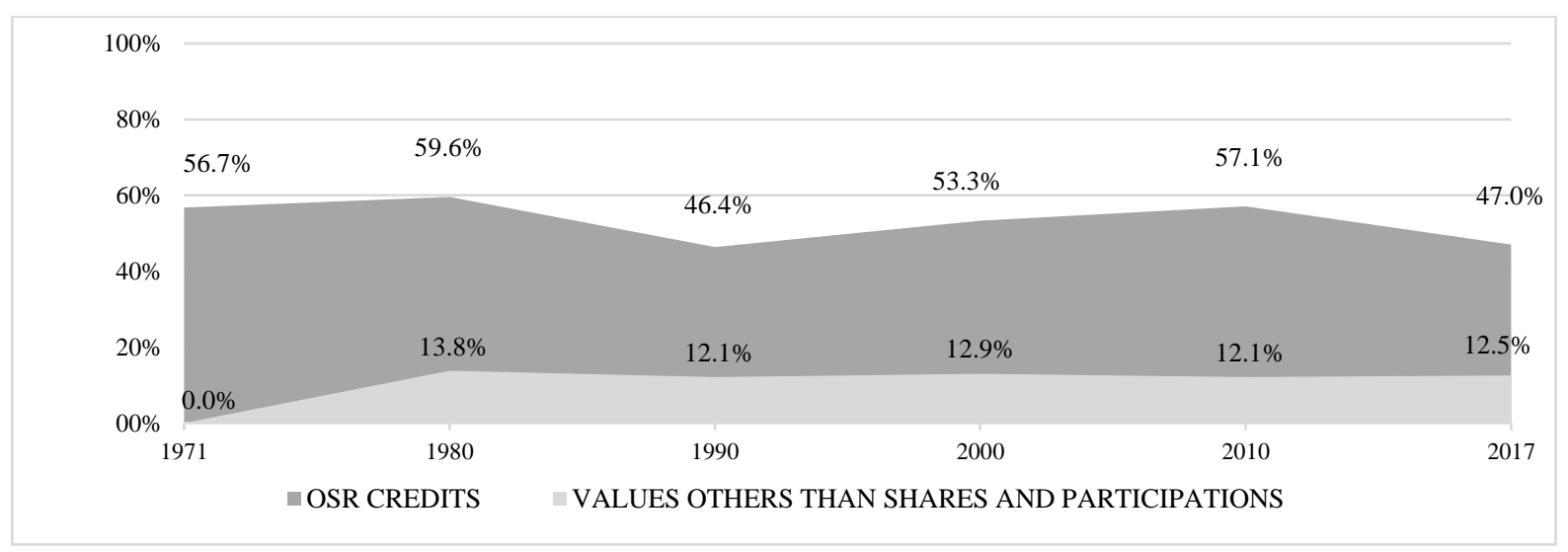

Figure 1. ORS credits and values other than shares and participations on total assets Source: Own elaboration based on Bank of Spain data.

With regard to total assets, in the last seven years, there was a reduction from $3,119,257.10$ million euros in 2010 to $2,550,188,10$ million euros in 2017 ; that is, a decrease of $18.2 \%$ in the economic structure of the Spanish banking system. It is important to mention that the deterioration of the portfolio due to the crisis was the main cause of the fall of the total assets of the system. It is also important to mention that in June 2017, Banco Popular, the fourth largest bank in Spain, was bought out by Banco Santander, the largest Spanish bank.

b. Liabilities: As shown in Table 3, liabilities grew in current terms by $14,585.7 \%$, specifically from 15,713 million euros in 1971 to 2,203,211,50 million in 2017 (INE). As can be seen in Table 3, deposits were the main source of financing for the banking institutions in the 1970s. Thus, in 1971 this item accounted for $90.4 \%$ of the total liabilities and equity $(15,238.7$ million/ 16,854.9 million euros). However, deposits gradually lost predominance in later decades. At the end of 2017, deposits accounted for 70.8\% (1,805,740.5 million/ 2,550,188.1 million euros). 
INTERDISCIPLINARY APPROACH TO ECONOMICS AND SOCIOLOGY

Table 3. System's consolidated liabilities and equity - Dec. 31, 1971 to Dec. 31, 2017 (000 euros)

\begin{tabular}{|c|c|c|c|c|c|c|}
\hline LIABILITIES & 1971 & 1980 & 1990 & 2000 & 2010 & 2017 \\
\hline DEPOSITS & $15,238,697$ & $85,069,944$ & $309,583,604$ & $789,690,765$ & $2,244,624,468$ & $1,805,740,472$ \\
\hline Credit system & $2,386,914$ & $11,294,977$ & $55,012,255$ & $139,705,861$ & $236,123,047$ & $293,383,380$ \\
\hline Public Administrations and Provisions & 133,112 & 888,182 & $11,194,367$ & $19,993,647$ & $75,287,050$ & $60,910,483$ \\
\hline ORS & $11,944,760$ & $61,781,836$ & $204,629,954$ & $401,173,026$ & $1,434,103,776$ & $1,193,835,580$ \\
\hline External sector & 773,911 & $11,104,949$ & $38,747,028$ & $228,818,231$ & $499,110,595$ & $257,611,029$ \\
\hline FIXED INCOME SECURITIES ISSUED & 227,597 & $2,039,096$ & $4,531,397$ & $39,941,027$ & $377,454,686$ & $200,289,371$ \\
\hline ACCRUALS AND OTHER LIABILITIES & 246,758 & $2,470,707$ & $27,248,855$ & $67,735,400$ & $224,072,203$ & $197,181,667$ \\
\hline TOTAL LIABILITIES & $15,713,052$ & $89,579,747$ & $\mathbf{3 4 1 , 3 6 3 , 8 5 6}$ & $897,367,192$ & $\mathbf{2 , 8 4 6 , 1 5 1 , 3 5 7}$ & $\mathbf{2 , 2 0 3 , 2 1 1 , 5 1 0}$ \\
\hline \multicolumn{7}{|l|}{ EQUITY } \\
\hline SHAREHOLDER'S EQUITY & $1,106,512$ & $6,835,480$ & $29,388,356$ & $72,480,923$ & $174,138,646$ & $218,880,620$ \\
\hline Capital & 381,222 & $2,202,842$ & $6,478,724$ & $10,438,709$ & $25,293,197$ & $52,207,199$ \\
\hline Reserves & 545,527 & $3,938,619$ & $17,724,244$ & $53,777,522$ & $134,679,887$ & $173,715,300$ \\
\hline Net Profit & 179,763 & 694,019 & $5,185,388$ & $8,264,692$ & $9,287,371$ & $-3,769,289$ \\
\hline Other accounts & 0 & 0 & 0 & 0 & $4,878,191$ & $-3,272,590$ \\
\hline VALUE ADJUSTMENTS & 0 & 0 & 0 & 0 & $-3,254,127$ & $1,968,981$ \\
\hline $\begin{array}{l}\text { VALUE ADJUSTMENTS FINANC. ASS. } \\
\text { and LIAB. }\end{array}$ & 0 & 0 & 0 & 0 & $12,089,406$ & $3,034,595$ \\
\hline $\begin{array}{l}\text { VALUATION ADJUST. DUE TO ASSET } \\
\text { IMPAIRM. }\end{array}$ & 0 & 0 & $5,676,120$ & $16,475,187$ & $86,914,327$ & $122,985,107$ \\
\hline SOCIAL AND CHARITABLE WORK & 35,352 & 154,857 & 836,909 & $1,526,054$ & $3,217,449$ & 107,288 \\
\hline TOTAL EQUITY & $1,141,864$ & $6,990,337$ & $35,901,385$ & $90,482,164$ & $273,105,701$ & $346,976,591$ \\
\hline TOTAL LIABILITIES AND EQUITY & $16,854,916$ & $96,570,084$ & $377,265,241$ & $987,849,356$ & $3,119,257,058$ & $2550,188,101$ \\
\hline
\end{tabular}

Source: Own elaboration and consolidation data based on Bank of Spain data.

Fixed income securities issued - purchased mainly with European Central Bank funds - had become more popular in the financial structure of the system (Baker \& Wurgler, 2002). Figure 2 illustrates this situation as well as the gradual participation of deposits in financing the total assets of the system.

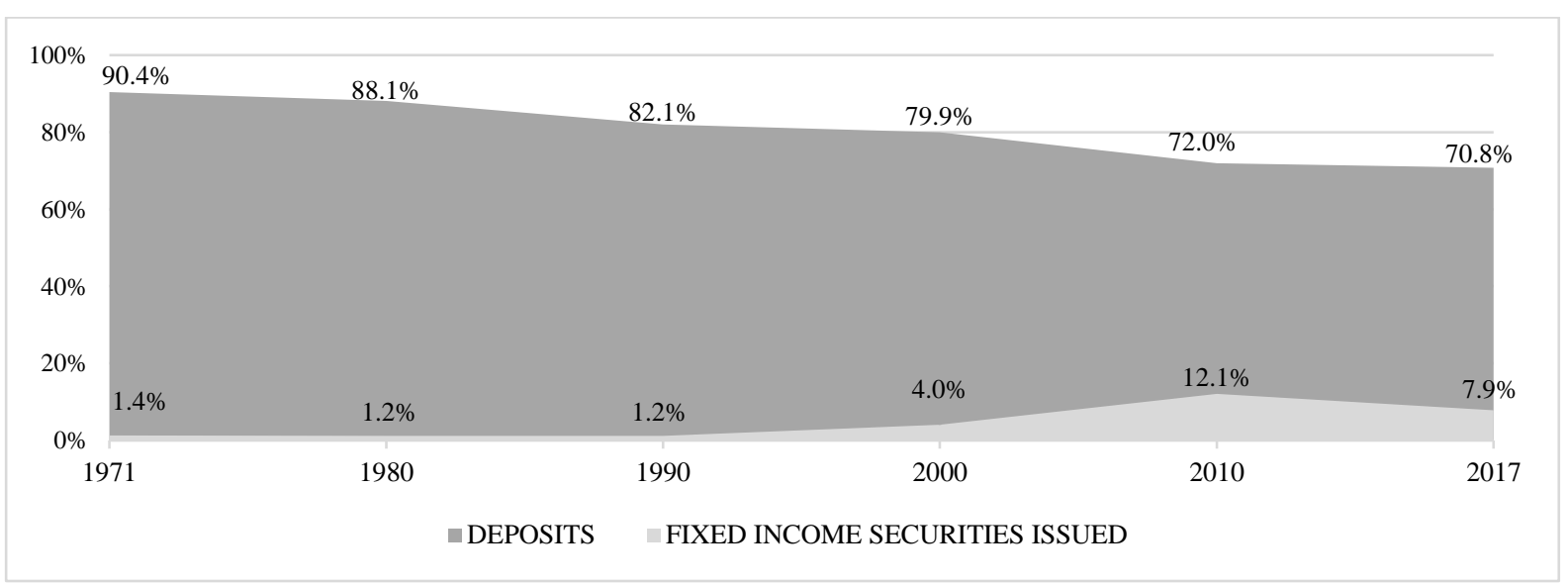

Figure 2. Deposits and fixed income securities issued on liabilities and equity Source: Own elaboration based on Bank of Spain data.

c. Equity: The growth of equity was $30,971.0 \%$ in current values. Specifically, equity increased from 1,141.8 million euros in 1971 to $346,976.6$ million in $2017(1,708.3 \%$ in constant terms). As can be observed in Table 3, this item represented $6.8 \%$ of total assets (1,141.9 million/16,854.9 million euros) in 1971 (Fama \& French, 2002). Over the decades, this percentage increased and in 2017 it reached $13.6 \%$, indicating a major improvement in 
the banks' solvency for the term under study (Elsinger \& Summer, 2010). It is worth highlighting that in 2010 equity was $8.8 \%$ on the assets and, at a first glance, the $4.8 \%$ increase in seven years $(13.6 \%-8.8 \%)$ would indicate a substantial improvement (Millán \& Fruet-Cardozo, 2012a). However, this was mainly financed with funds from the financial restructuring and bailout programs for the savings banks and the banks of the system that were in trouble, which reached 99,618 million euros (Bank of Spain, 2016) from 2009 to 2015. After this year, no more bailout funds were given. The detail of it is presented below.

Table 4. Restructuring and bailouts of Spanish deposit institutions between 2009-2015

\begin{tabular}{|c|c|c|}
\hline Spanish deposit institutions & Millions of $€$ & $\%$ \\
\hline Bankia & 36,183 & $36.3 \%$ \\
\hline Caja de Ahorros del Mediterráneo (CAM) & 13,222 & $13.3 \%$ \\
\hline Banco de Valencia & 7,223 & $7.3 \%$ \\
\hline Banco Mare Nostrum (BMN) & 3,745 & $3.8 \%$ \\
\hline Banco Ceiss & 2,247 & $2.3 \%$ \\
\hline Banco Grupo Caja 3 & 1,097 & $1.1 \%$ \\
\hline Banco Gallego & 867 & $0.9 \%$ \\
\hline Cajasur & 358 & $0.4 \%$ \\
\hline Banca Cívica & 977 & $1.0 \%$ \\
\hline Unnim Banc & 1,992 & $2.0 \%$ \\
\hline Caja Castilla La Mancha y Liberbank & 6,974 & $7.0 \%$ \\
\hline NCG Banco & 11,081 & $11.1 \%$ \\
\hline Catalunya Banc & 13,652 & $13.7 \%$ \\
\hline Total & 99,618 & $100.0 \%$ \\
\hline
\end{tabular}

Source: Own elaboration and consolidation data based on Bank of Spain data.

That is, the bailout using funds collected from the Spanish taxpayers and not from resources of the institutions themselves. But this is another matter that is not under study in this paper.

It is important to mention that the capital increased in current terms by $15,160.9 \%$ from 381.2 million euros in 1971 to 52,207.2 million in 2017. On the other hand, reserves constituted the main item of shareholders' equity. In 1971 this was 545.5 million euros, which represented $3.2 \%$ of the financial structure. In 2017 this reached 173,715.3 million euros, which represented $6.8 \%$ (Baker and Wurgler, 2002). The reserves for valuation adjustments due to assets impairment deserve special attention. We have data for this item for the year 2005, a year in which an amount of $23,885.5$ million euros was reported, representing $1.2 \%$ of the total financial structure. In 2017, the amount increased to 122,985.1 million euros, which represented $4.8 \%$. This evolution is due to the impact of the economic crisis in the banking sector (European Banking Authority, 2014a; Jobst et al., 2013).

\subsection{Comments on the consolidated income statement}

The income statement is presented in Table 5, which shows that for the first 22 years (1971 to 1993) the increase in financial products has been continuous and positive, with a mean growth of $17.6 \%$. However, there were significant decreases in several years in the period 1994-2017, with a mean increase of just $-0.8 \%$. 
INTERDISCIPLINARY APPROACH TO ECONOMICS AND SOCIOLOGY

Table 5. System's consolidated income statements - Dec. 31, 1971 to Dec. 31, 2017 (000 euros)

\begin{tabular}{lrrrrrr}
\hline \multicolumn{1}{c}{ REVENUE AND EXPENSES } & $\mathbf{1 9 7 1}$ & $\mathbf{1 9 8 0}$ & $\mathbf{1 9 9 0}$ & $\mathbf{2 0 0 0}$ & \multicolumn{1}{c}{$\mathbf{2 0 1 0}$} & \multicolumn{1}{c}{$\mathbf{2 0 1 7}$} \\
\hline Financial products & 947,544 & $10,485,341$ & $44,772,859$ & $46,580,768$ & $77,091,165$ & 33.027 .902 \\
\hline Financial expenses & 478,880 & $6,332,630$ & $29,775,224$ & $28,236,176$ & $42,798,951$ & 9.799 .390 \\
\hline Interest margin & $\mathbf{4 6 8 , 6 6 4}$ & $\mathbf{4 , 1 5 2 , 7 1 1}$ & $\mathbf{1 4 , 9 9 7 , 6 3 5}$ & $\mathbf{1 8 , 3 4 4 , 5 9 2}$ & $\mathbf{3 4 , 2 9 2 , 2 1 4}$ & 23.228 .512 \\
\hline Income from equity instr. \& other products \& expenses & 61,598 & 599,389 & $2,795,716$ & $12,109,730$ & $29,020,664$ & 23.508 .567 \\
\hline Gross margin & $\mathbf{5 3 0 , 2 6 2}$ & $\mathbf{4 , 7 5 2 , 1 0 0}$ & $\mathbf{1 7 , 7 9 3 , 3 5 1}$ & $\mathbf{3 0 , 4 5 4 , 3 2 2}$ & $\mathbf{6 3 , 3 1 2 , 8 7 8}$ & 46.737 .079 \\
\hline Operating expenses & 342,667 & $3,324,787$ & $10,942,273$ & $19,158,433$ & $29,431,088$ & 26.667 .347 \\
\hline Staff costs & 240,639 & $2,261,362$ & $6,800,896$ & $11,600,891$ & $17,642,567$ & 13.934 .507 \\
\hline Net provisions & 0 & 45,899 & $1,513,716$ & $3,103,397$ & $3,963,156$ & 3.597 .055 \\
\hline Loss due to impairment of financial assets & 7,519 & 543,207 & $1,150,890$ & $2,116,277$ & $16,718,935$ & 9.126 .880 \\
\hline Net operating income & $\mathbf{1 8 0 , 0 7 6}$ & $\mathbf{8 3 8 , 2 0 7}$ & $\mathbf{4 , 1 8 6 , 4 7 2}$ & $\mathbf{6 , 0 7 6 , 2 1 5}$ & $\mathbf{1 3 , 1 9 9 , 6 9 9}$ & 7.345 .797 \\
\hline Losses due to impairment of other assets & 0 & 108,627 & $-39,834$ & $\mathbf{3 3 , 7 6 5}$ & $5,290,339$ & 9.275 .528 \\
\hline Other income or loss & 4,682 & 84,208 & $1,059,449$ & $\mathbf{3 , 7 5 9 , 2 8 8}$ & $1,927,240$ & 1.433 .297 \\
\hline Profit before tax (up to 1991) & $\mathbf{1 8 4 , 7 5 8}$ & $\mathbf{8 1 3 , 7 8 8}$ & $\mathbf{5 , 2 8 5 , 7 5 5}$ & $\mathbf{9 , 8 0 1 , 7 3 8}$ & $9,836,600$ & -496.434 \\
\hline Companies Tax & 0 & 0 & 0 & $1,516,549$ & 133,823 & 3.216 .749 \\
\hline Provisions for Social and Charitable Work (SCW) & 0 & 0 & 0 & 0 & 30,049 & 56.106 \\
\hline Net benefit (from 1992) & $\mathbf{0}$ & $\mathbf{0}$ & $\mathbf{0}$ & $\mathbf{8 , 2 8 5 , \mathbf { 1 8 9 }}$ & $\mathbf{9 , 6 7 2 , 7 2 8}$ & -3.769 .289 \\
\hline
\end{tabular}

Source: Own elaboration and consolidation data based on Bank of Spain data.

From 2005 onwards, an increase typical of a financial bubble period was seen. That year, financial products amounted to 57,526.8 million, whereas in 2008 they reached 141,653.6 million, which could not be considered a normal growth in this sector. The above amounts are shown in Figure 3.

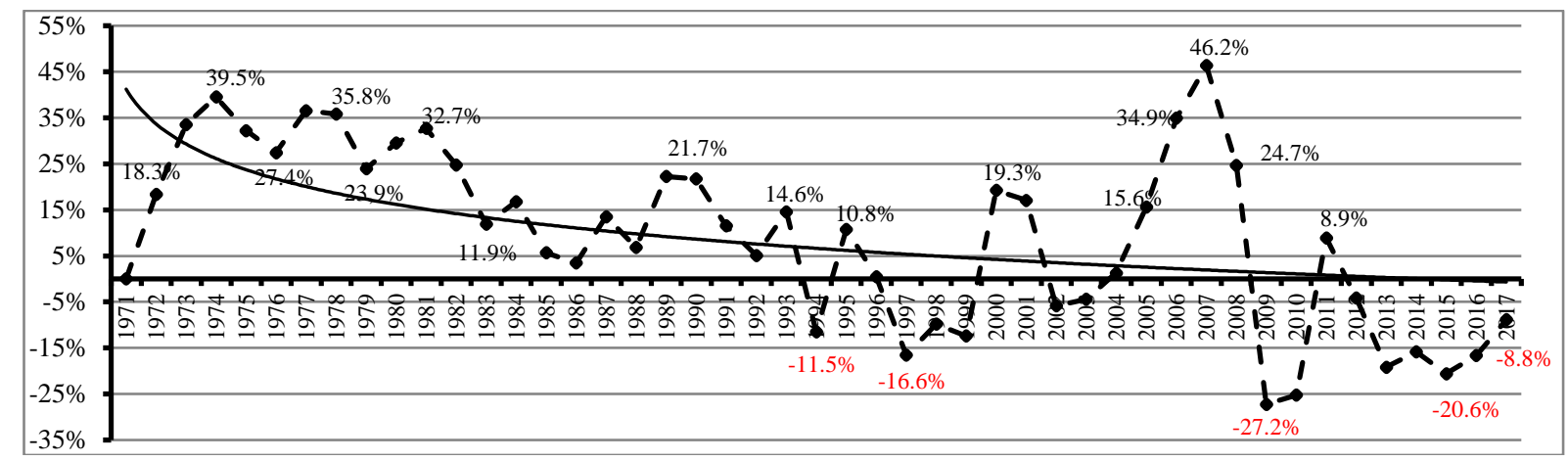

Figure 3. Financial products - annual growth

Source: Own elaboration and consolidation data based on Bank of Spain data.

Moreover, the mean gross margins for the decades under analysis were $46.2 \%, 37.9 \%$, $34.2 \%, 39.2 \%$, and $45.3 \%$ in the $1970 \mathrm{~s}, 1980 \mathrm{~s}, 1990 \mathrm{~s}, 2000$ to 2009, and 2010 to 2015, respectively. This would indicate the application of an adequate spread (Rose, 2002).

The net operating income in 1971 was initially $19.0 \%$ of the financial products $(180.1$ million/ 947.5 million euros); with operating expenses representing $36.2 \%$ of financial products, of which $25.4 \%$ were staff costs. 2012 was the only year in which the net operating income yielded a negative figure due to the restructuring of the portfolio of the so-called "toxic assets" originated during the recession years. Thus, that year the loss due to the impairment of financial assets even exceeded the system's financial income: $102.6 \%(82,547.5$ million/80,464.5 million euros). In 2017, operating expenses increased to $80.7 \%$ of the financial products, of which $42.2 \%$ were staff costs, therefore significantly increasing structural costs during the years of declining operating income.

Figure 4 shows the behaviour of the profitability indicators ROE and ROA. From 1971 to 1992 these indicators yielded excellent outcomes. For those 22 years, the ROA was at a mean 
of $1.0 \%$ and the ROE at $12.9 \%$. In 1993, both indicators showed a notable reduction, but from that year until the start of the economic recession in Spain in 2008, the decrease was greater. The worst outcomes occurred in 2011, 2012. and 2017, with $-0.5 \%,-2.3 \%$ and $-0.2 \%$ for the ROA and $-4.2 \%,-18.8 \%$ and $-1.1 \%$ for the ROE. These figures reflect the effects of the restructuration of the financial sector as a result of the global crisis. However, despite the strong impact this had on the Spanish banking sector, all the capital increases made during the period under study support the hypothesis of this research.

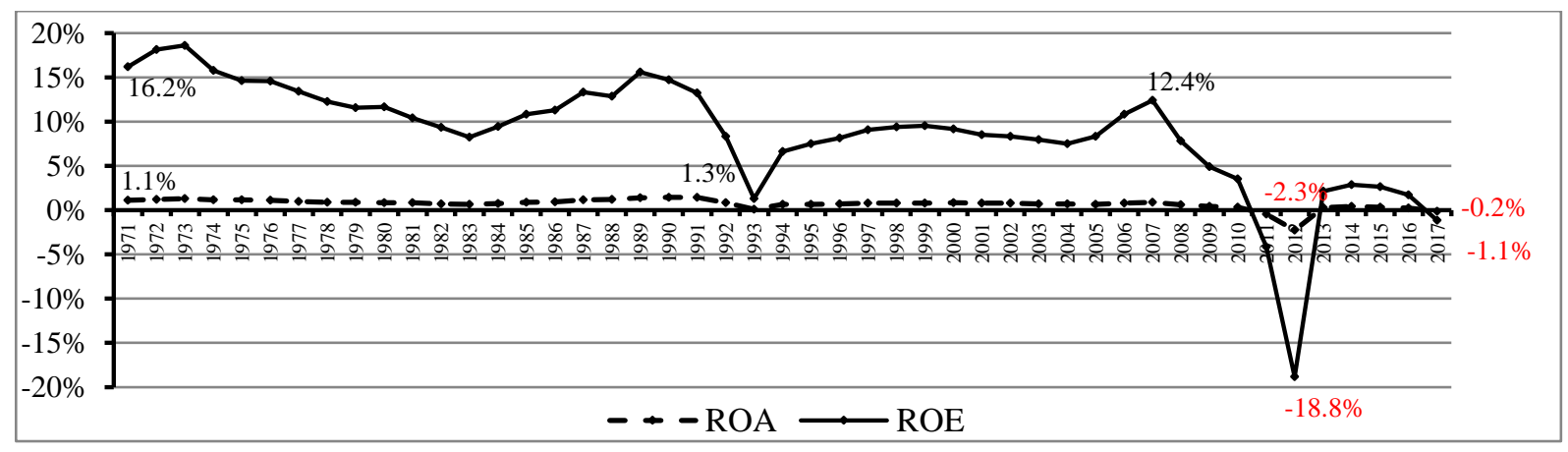

Figure 4. Evolution of ROA and ROE from 1971 to 2015

Source: Own elaboration and consolidation data based on Bank of Spain data.

\subsection{Proposed model specification}

Figure 5 shows the goodness-of-fit of the model based on the data. As can be seen, some small changes have been made in relation to the original model in order to achieve a better fit. For instance, the variable X2 = Capital/Assets has been eliminated due to the lack-of-fit of the model. Therefore, the final variables that represent the model are shown in Table 6.

Table 6. Variables and definitive ratios selected for the analysis

\begin{tabular}{clcc}
\hline Acronym & & Ratios & Type of variables \\
\hline X1 & Increase in ROE & & \\
X2 & Capital Increase & Indebtedness & \\
X3 & Equity/Assets & Indebtedness & Exogenous \\
X4 & Liabilities/Assets & Indebtedness & \\
X5 & Equity/Liabilities & Efficiency & \\
Y1 & Net benefit & Profitability & \\
Y2 & ROA & Profitability & Endogenous \\
Y3 & Administrative Costs/Operating Inc. & Profitability & \\
Y4 & Intermediation Margin & Solvency & \\
e1 & & & Error variables \\
e2 & & & \\
e3 & & & \\
e4 & & & \\
\hline
\end{tabular}

SPSS 23 and AMOS software were used to create the diagram. SPSS, which runs as a command, allows the specification, estimation, evaluation, and presentation of models in order to show hypothetical associations between the variables described above (Caridad y Ocerín, 2016). The rectangles represent the observable exogenous and endogenous variables. The arrows represent the connections between regressions and correlations. The two-pointed arrows indicate the covariances. 
In general and specific terms, the diagram shows a statistical model that adequately fits the hypothesis: increases in the capital of Spanish Banks led to an increase in both solvency and profitability.

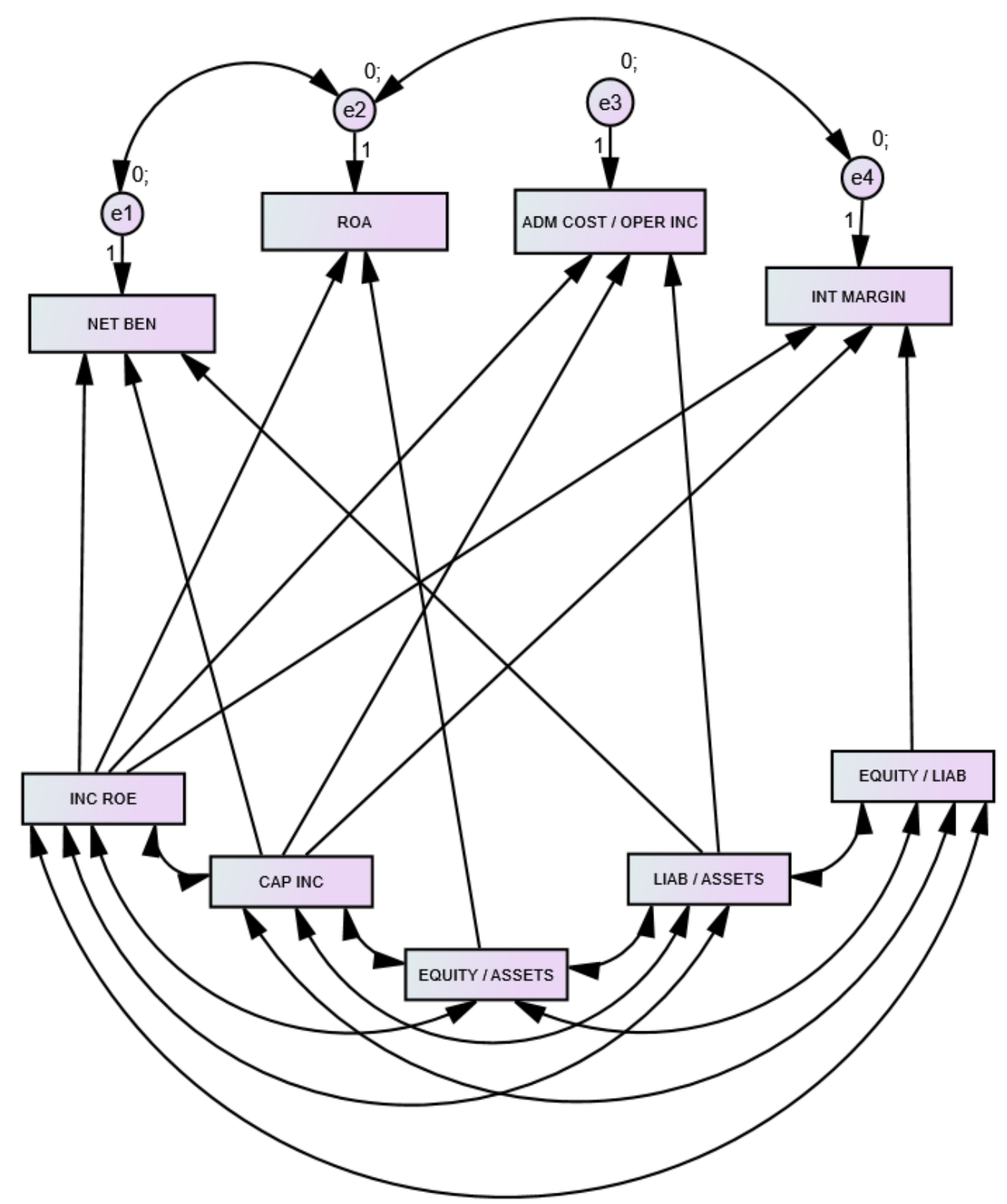

Figure 5. Goodness-of-fit of the SEM, path analysis

Source: Own elaboration using AMOS software

\section{Conducting research and results}

All the parameters were estimated using the maximum likelihood estimation. The estimated coefficients are all significant at 5\% and almost all at $1 \%$, which supports the specification of the model. The values of the regressions are shown in Table 7. 
INTERDISCIPLINARY APPROACH TO ECONOMICS AND SOCIOLOGY

Table 7. Regression weights

\begin{tabular}{|c|c|c|c|c|c|}
\hline \multicolumn{2}{|c|}{ Variables } & \multirow{2}{*}{$\begin{array}{c}\text { Estimate } \\
26.267\end{array}$} & \multirow{2}{*}{$\begin{array}{c}\text { S.E. } \\
5.875\end{array}$} & \multirow{2}{*}{$\begin{array}{c}\text { C.R. } \\
4.471\end{array}$} & \multirow{2}{*}{$\begin{array}{c}\boldsymbol{p} \\
* * *\end{array}$} \\
\hline Net Ben. & $\leftarrow$ Inc.ROE & & & & \\
\hline ROA & $\leftarrow$ Inc.ROE & 0.455 & 0.041 & 10.976 & $* * *$ \\
\hline Net Ben. & $\leftarrow$ Cap.Inc. & -0.360 & 0.182 & -1.978 & 0.048 \\
\hline Adm.C./Op.Inc. & $\leftarrow$ Cap.Inc. & 0.005 & 0.001 & 4.094 & $* * *$ \\
\hline Int.Marg. & $\leftarrow$ Cap.Inc. & -0.016 & 0.002 & -7.740 & $* * *$ \\
\hline ROA & $\leftarrow$ Eq./Ass. & 0.661 & 0.041 & 15.991 & $* * *$ \\
\hline Net Ben. & $\leftarrow$ Liab./Ass. & -27.063 & 5.720 & -4.731 & $* * *$ \\
\hline Adm.C./Op.Inc. & $\leftarrow$ Liab./Ass. & 0.926 & 0.035 & 26.673 & $* * *$ \\
\hline Int.Marg. & $\leftarrow$ Eq./Liab. & 1.289 & 0.056 & 22.973 & $* * *$ \\
\hline Adm.C./Op.Inc. & $\leftarrow$ Inc.ROE & 0.098 & 0.036 & 2.735 & 0.006 \\
\hline Int.Marg. & $\leftarrow$ Inc.ROE & -0.239 & 0.058 & -4.101 & $* * *$ \\
\hline
\end{tabular}

Source: Compilation data using AMOS software.

In general, all the findings obtained can be considered adequate, thus indicating that the model fits the initial hypothesis. The values of the covariances and variances are shown in tables 8 and 9 , respectively.

Table 8. Covariances

\begin{tabular}{|c|c|c|c|c|c|}
\hline \multicolumn{2}{|c|}{ Variables } & \multirow{2}{*}{$\begin{array}{c}\text { Estimate } \\
-0.215 \\
\end{array}$} & \multirow{2}{*}{$\begin{array}{c}\text { S.E. } \\
0.090\end{array}$} & \multirow{2}{*}{$\frac{\text { C.R. }}{-2.376}$} & \multirow{2}{*}{$\begin{array}{c}\boldsymbol{p} \\
0.017\end{array}$} \\
\hline Inc.ROE & $\leftrightarrow \quad$ Cap.Inc. & & & & \\
\hline Eq./Ass. & $\leftrightarrow \quad$ Liab./Ass. & 0.059 & 0.012 & 4.790 & $* * *$ \\
\hline Liab./Ass. & $\leftrightarrow \quad$ Eq./Liab. & 0.058 & 0.012 & 4.779 & $* * *$ \\
\hline Inc.ROE & $\leftrightarrow$ Eq./Ass. & 0.055 & 0.012 & 4.658 & $* * *$ \\
\hline Inc.ROE & $\leftrightarrow \quad$ Liab./Ass. & 0.056 & 0.012 & 4.679 & $* * *$ \\
\hline Inc.ROE & $\leftrightarrow \quad$ Eq./Liab. & 0.055 & 0.012 & 4.632 & $* * *$ \\
\hline Cap.Inc. & $\leftrightarrow$ Eq./Ass. & -0.152 & 0.088 & -1.734 & 0.083 \\
\hline Cap.Inc. & $\leftrightarrow \quad$ Liab./Ass. & -0.171 & 0.088 & -1.936 & 0.053 \\
\hline Cap.Inc. & $\leftrightarrow \quad$ Eq./Liab. & -0.150 & 0.088 & -1.702 & 0.089 \\
\hline Eq./Ass. & $\leftrightarrow \quad$ Eq./Liab. & 0.059 & 0.012 & 4.792 & $* * *$ \\
\hline $\mathrm{e} 2$ & $\leftrightarrow \quad \mathrm{e} 4$ & 0.002 & 0.001 & -2.354 & 0.019 \\
\hline e1 & $\leftrightarrow \quad \mathrm{e} 2$ & 0.020 & 0.009 & 2.161 & 0.031 \\
\hline
\end{tabular}

Source: Compilation data using AMOS software.

Table 9. Variances

\begin{tabular}{lcccc}
\hline \multicolumn{1}{c}{ Variables } & Estimate & S.E. & C.R. & $\boldsymbol{p}$ \\
\hline Inc.ROE & 0.059 & 0.012 & 4.795 & $* * *$ \\
\hline Cap.Inc. & 5,642 & 1.176 & 4.797 & $* * *$ \\
\hline Eq./Ass. & 0.059 & 0.013 & 4.796 & $* * *$ \\
\hline Liab./Ass. & 0.059 & 0.011 & 4.795 & $* * *$ \\
\hline Eq./Liab. & 0.059 & 0.012 & 4.794 & $* * *$ \\
\hline e1 & 7.827 & 1.632 & 4.793 & $* * *$ \\
\hline e2 & 0.005 & 0.001 & 4.856 & $* * *$ \\
\hline e3 & 0.004 & 0.001 & 4.797 & $* * *$ \\
\hline e4 & 0.001 & 0.000 & 4.796 & $* * *$ \\
\hline
\end{tabular}

Source: Compilation data using AMOS software. 
Following Browne and Mels (1992) and Browne and Cudeck (1993), we present the main research findings below.

\subsection{Global test for the model (CMIN)}

The chi-square statistic (CMIN) is the only measure of the goodness-of-fit associated to a global significance test which is a prerequisite to accept the model. However, some additional individual tests are necessary to assess the significance of each parameter, the remaining measures and goodness-of-fit indexes (Caridad y Ocerín, 2016). In this regard, the result obtained with $\chi^{2}$ is very good: 17.716 with 13 degrees of freedom (DF), the number for testing the model with $p=0.169$, and to test the hypothesis that the model can be considered adequate. Therefore, it can be stated that the $\chi^{2}$ obtained confirms the hypothesis of the goodness-of-fit of the model with the 450 cases of observed data.

\subsection{Goodness-of-fit indexes}

In SEM models, several measures of goodness-of-fit are employed according to different criteria. The most common are presented here, although the AMOS software includes some additional measures and provides an interval for each: the optimal value (that is, the figure associated to a perfect fit linked to the saturated model) and, at the other extreme, the value associated to the independence model. This helps to interpret some statistics that do not have a bounded range (such as a likelihood-based measures). Goodness-of-fit measures can be classified into three broad groups: those based on the covariance matrix of the observed data, the statistics that compare the proposed model to the independence model, and finally, those derived from the likelihood function.

In the first class, besides the chi-square statistic, the root mean square error (RMSEA) is the basis on which to judge the size of the residuals (differences between the observed and the model-estimated covariances of the numerical variables). In our case, RMSEA $=0.089$, which is below the 0.1 threshold usually used to cap the mean square residuals; the optimal value for the saturated model is 0 and the upper limit is unbounded. An additional goodnessof-fit in this class is the root mean square of the normalised residuals, which provides a similar view.

The second group of measures compares the proposed model to the independence model (Browne and Cudeck, 1993). The two usual statistics are the Tucker-Lewis (NFI =0.987) and the Bentler index $(\mathrm{CFI}=0.997)$, which are related to the proportion of covariance explained by the model (the optimal covariance corresponding to the saturated model is 1 , which is a perfect fit). In our case, these statistics are very close to the saturated model, thus confirming our model.

Finally, a third group of goodness-of-fit measures are based on the likelihood function associated to the specified model (Caridad y Ocerín, 2016). Common measures in this group are the Akaike information criterion (AIC) or the Schwarz-Bayesian Information criterion (BIC). These measures are used to compare models with a different number of parameters in order to obtain minimum values. In our case, AIC $=81.716$, which is close to the minimum limit associated to the saturated model.

\section{Discussion}

This research synthesizes information related to the economic-financial and patrimonial situation of Spanish banks for 47 years, from 1971 to 2017. The main objective is to provide empirical evidence on how capital increases imply an increase not just in solvency, but also 
profitability, which have been analysed using financial ratios and a structural equation model (SEM). Also, in the Introduction we mentioned our concern about the change that the main role of the banking system has had in recent decades, not only in Spain and in the EU, but worldwide. And our restlessness increases when we see that the requirements demanded by the most important control and consulting agencies in the world, such as the Basel Committee, for example, do not require with determination that the bank's equity be a real support of creditors, investors and general public. In this regard, the 8\% required by Core Tier 1 and applied in the stress tests conducted by the European Banking Authority (EBA) may not be enough (EBA, 2014b).

Therefore, in order to further support our hypothesis, the Tier Core 1 formula is briefly explained. Subsequently, a consolidated report of the European Central Bank (ECB) on the profit, equity, and ROE of Eurozone banks is presented.

\subsection{Core Tire 1}

The Basel Committee standards are minimum requirements which apply to banks internationally. Basel III focuses not only on different components of regulator capital, but also on the so-called "risk-weighted assets" (RWA).

As regards the regulatory capital base, banks usually finance their investments with capital and debt, such as customer deposits. Regulatory capital is composed of (i) Common Equity Tier 1: common shares, retained earnings, and other reserves; (ii) Additional Tier 1: capital instruments with no fixed maturity among others; and, (iii) Tier 2: subordinated debt and general loan-loss reserves.

As for RWA, banks typically hold cash, securities, and loans and a risk weight is assigned to each type of asset: credit risk; market risk, and operational risk (Millán and FruetCardozo, 2012b).

$$
\text { Core Tier } 1=\frac{\text { Regulatory Capital base }}{\text { Risk weighted assets }} \geq 8 \%
$$

Additionally, to support our hypothesis, an ECB report on Eurozone banks, their capital and ROE increases from December 2005 to December 2017 led to similar conclusions.

\subsection{ECB data from banks in the Eurozone}

The profit, equity, and ROE of Eurozone banks from December 2005 to December 2017 can be observed in (ECB, 2019).

As a result of the last financial crisis, profits dropped from 2.67 to 0.87 billion euros in the period 2007-2008, leading to a decrease in ROE from $22.9 \%$ to $7.5 \%$. Despite this turbulent period of contemporary economic history, during which the levels of equity observed in the report have been maintained somewhat (in some cases thanks to the bailout mentioned in section 2.3), ROE shows a permanent upward trend during the 12 years.

Similarly, the Spanish banking system recovered after the 2008 crisis. The recovery has been the result of two factors: (i) the most important one was the increase in equity thanks to the bailouts, which were EU resources and, to a lesser extent, (ii) the new regulations of the international banking supervision body, whose main activity is to conduct stress tests for banks on a regular basis. Although in our opinion this supervisory body does not firmly control solvency, it does at least encourage banks to avoid being poorly positioned in the publications of the respective test. 
Table 10. Consolidated equity and ROE of Eurozone banks (billions of euros)

\begin{tabular}{cccc}
\hline Date & Profit & Equity & ROE \\
& (Billions & of Euros) & \\
\hline 2005-Dec-31 & $1.37 €$ & $€ 12.29$ & $11.1 \%$ \\
2006- Dec -31 & $1.42 €$ & $€ 10.39$ & $13.6 \%$ \\
2007- Dec -31 & $2.67 €$ & $€ 11.66$ & $22.9 \%$ \\
2008- Dec -31 & $0.87 €$ & $€ 11.59$ & $7.5 \%$ \\
2009- Dec-31 & $1.09 €$ & $€ 11.07$ & $9.8 \%$ \\
2010- Dec-31 & $1.65 €$ & $€ 13.33$ & $12.3 \%$ \\
2011- Dec -31 & $1.79 €$ & $€ 11.54$ & $15.5 \%$ \\
2012- Dec -31 & $2.02 €$ & $€ 11.15$ & $18.1 \%$ \\
2013- Dec -31 & $1.37 €$ & $€ 11.47$ & $12.0 \%$ \\
2014- Dec -31 & $1.71 €$ & $€ 11.36$ & $15.1 \%$ \\
2015- Dec -31 & $1.83 €$ & $€ 12.43$ & $14.7 \%$ \\
2016- Dec -31 & $2.08 €$ & $€ 12.79$ & $16.2 \%$ \\
2017- Dec -31 & $1.79 €$ & $€ 12.55$ & $14.3 \%$ \\
\hline
\end{tabular}

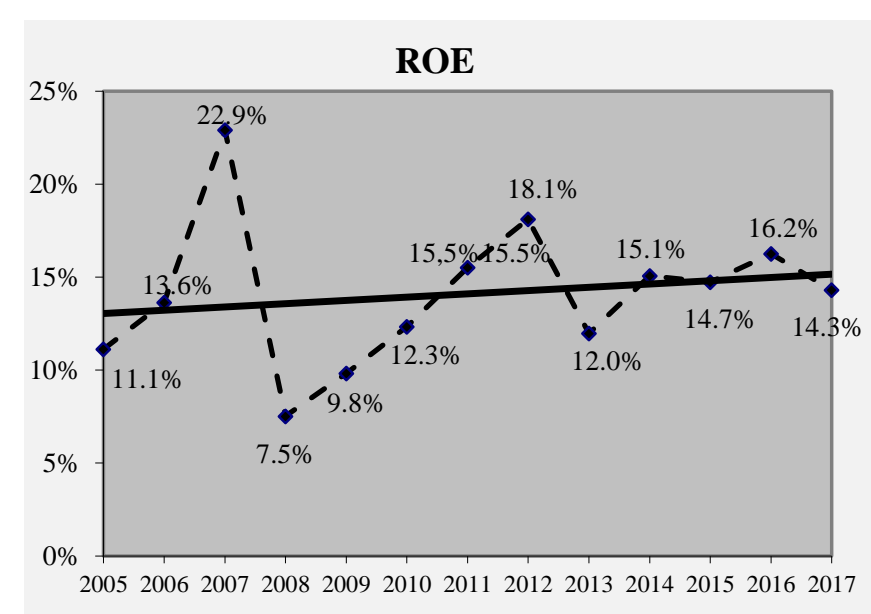

Figure 6. ROE trend - Eurozone banks

Source: Own elaboration based on ECB data

Finally, although the SEM shows evidence of how capital increases positively impact the profitability of banking entities, the new banking supervision regulations (ECB, 2014) did not consider a key issue: the incidence of bank financing costs. In this regard, the regulation is based on not increasing the cost of financing banks, since improving the financial structure by increasing own resources would be set off by reducing the risk profile of the banking entities (Dermine, 2013). According to King (2009), the cost of banking entities' capital depends on the risk perceived by the markets and the possibility for banks to have state economic support in case of insolvency.

\section{Conclusion}

The almost five decades of data analysed show how the Spanish banking system has undergone fundamental changes. The 'Equity/Liabilities' solvency ratio, for example, has increased from $7.3 \%$ to $13.6 \%$ in the period 1971-2017. Similarly, in terms of profitability, from 1971 to 2007, the year that marked the beginning of the last global economic and financial crisis, the ROE of the Spanish banking system obtained an average of $11.1 \%$. Moreover, considering the whole period, that is, including the poor results of the crisis years, the average was $9.0 \%$, which would be more than satisfactory for the shareholders (Fama \& French, 2002). Therefore, from an economic and financial point of view, we can argue that our hypothesis is supported by the market data.

A SEM is proposed to link several variables from the banking sector consolidated liabilities, equity, revenue and expenses accounts, to explain some profitability and solvency measures dependent of several financial ratios of indebtedness and efficiency. The net benefit is explained by the increase in ROE and capital and by the ratio of liabilities to assets. The ROA is linked to this ratio and to variations in the ROE. The ratio of efficiency measured by the administrative costs over the operating income is explained by the increases in ROE and capital, 
as well as by the ratio of liabilities over assets. Finally, the increase in the operational margin is dependent on the variation in ROE and in capital and the ratio of equity over liabilities.

The proposed path analysis model is significant overall, as shown by the chi-square test. The estimated parameters are significant (with a $p$-value of less than $5 \%$ and, in most cases, less than 1\%) and the goodness-of-fit measures are, in all cases, close to the saturated model. For example, the RMSEA is 0.089 and the CFI is 0.997 (for a maximum value of 1), thus supporting the proposed model adequately.

With that in mind and from a debt perspective, we question if the ratio of debt to equity/total assets $=13.6 \%$ in December 2017 is sufficient (Dombret \& Lucius, 2013). Assumedly, the answer is yes. However, considering that the capital increase during the period 2011 to 2015 (in 2016 and 2017 the capital increases were based on increases in the reserves) was made possible through the financial restructuring and bailout money, it could be a virtual solvency. Therefore, under the assumption that $13.6 \%$ of the equity/assets ratio is not enough for a banking system to be considered solvent, how much capital is sufficient?

Leverage - which has become practically a dogma in the world of finance in recent decades (World Bank, 2016) - works when everything goes smoothly in the macroeconomic scenario. But when it begins to wobble and the first hurricane winds of financial storms arrive, the first companies to panic are the most leveraged ones. And these are usually those of the financial system. However, we would prefer to focus on this part of the proposal in future research.

Finally, given the oligopolistic structure of the Spanish banking system (Asociación Española de Banca, 2016), the proposal to increase the banks' capital with genuine funds from the entities would most likely not meet with approval. To sum up, based on our economic and financial analysis and supported by the statistical model presented, we are convinced that capital increases would lead not only to enhanced solvency, but also enhanced profitability.

\section{References}

Asociación Española de Banca. (2016). Financial statements. Retrieved from http://www.aebanca.es/EstadosFinancieros/index.htm

Asociación Española de Banca (2018). Financial statements. Retrieved from http://www.aebanca.es/EstadosFinancieros/index.htm

Aymanns, C., Cáceres, C., Daniel, C., \& Schumacher, L. (2016, March). Bank solvency and funding cost (Working Paper No. 16/64). Washington D.C., USA: International Monetary Fund.

Badri, M. A., \& Alshare, K. (2008). A path analytic model and measurement of the business value of e-government: An international perspective. International Journal of Information Management, 28, 524-535.

Badri, M. A., Davis, D., \& Davis, D. (2000). Operations strategy, environmental uncertainty and performance: a path analytic model of industries in developing countries. Omega, $28,155-173$.

Bagozzi. R. P., \& Heatherton, T. F. (1994). A general approach to representing multifaceted personality construct: Application to state self-esteem? Structural Equation Modeling, 1, 35-67.

Baker M., \& Wurgler, J. (2002). Market timing and capital structure. The Journal of Finance, 57, 1-32.

Bank of Spain (2016). Main data of the bank before the global evaluation. Public aid in the restructuring process. Retrieved from: http://www.bde.es/f/webbde/GAP/Secciones/SalaPrensa/ComunicadosBCE/NotasInfo rmativasBCE/14/Arc/Fic/plantilla.pdf 
Bassett, W. F., Lee, S. J., \& Spiller, T. P. (2015). Estimating changes in supervisory standards and their economic effects. Journal of Banking \& Finance, 57, 21-43.

Bentler, P. M. (1990). Comparative fit indexes in structural models. Psychological Bulletin, 107, 238-246,

Bollen, K. A. (1989). Structural equations with latent variables. New York, NY, USA: John Wiley \& Sons.

Borio, C., \& Drehmann, M. (2009, June). Towards an operational framework for financial stability: "Fuzzy" measurement and its consequences (Working Paper No. 284). Bank of International Settlements (BIS).

Browne, M. W., \& Cudeck, R. (1993). Alternative ways of assessing model fit. In K. A. Bollen and J. S. Long (Eds.), Testing structural equation models (pp. 136-162). Newbury Park, CA, USA.

Browne, M. W., \& Mels, G. (1992). RAMONA User's Guide. Columbus, OH, USA: The Ohio State University.

Calice, P. (2014, July). Predicting bank insolvency in the Middle East and North Africa. (Working Paper No. 6969). Washington D.C., USA: World Bank Economic Review.

Calvo, A., Parejo, J. A., Rodríguez, L., \& Cuervo, Á. (2010). Manual del sistema financiero español. Madrid, Spain: Editorial Ariel Economía.

Caridad y Ocerín, J. M. (2016). Modelos estructurales con AMOS [Structural models using AMOS]. Cordoba, Spain: Ediciones Don Folio.

Dermine, J. (2013). Banking regulations after the global financial crisis, good intentions and unintended evil. European Financial Management, 19, 658-674).

Dietrich, A., Hess, K., \& Wanzenried, G. (2014). The good and the bad news about the new liquidity rules on Basel III in Western European countries. Journal of Banking and Finance, 44, 13-25).

Dombret, A., \& Lucius, O. (2013). Stability of the financial system: Illusion or feasible concept? Cheltenham, UK: Edward Elgar.

Duncan, O. D. (1966). Path analysis: Sociological examples. The American Journal of Sociology, 72, 1-16.

Elosua, P. (2011). Subjective values of quality of life dimensions in elderly people: A SEM preference model approach. Social Indicators Research, 104, 427-437.

Elsinger, H., \& Summer, M. (2010). The economics of bank insolvency, restructuring and recapitalization (Financial Stability Report No. 20). European Central Bank.

European Banking Authority (2014a). 2014 EU-wide stress test results. Retrieved from http://www.eba.europa.eu/-/eba-publishes-2014-eu-wide-stress-test-result

European Banking Authority (2014b). Results of 2014 EU-wide stress test. Retrieved from http://www.eba.europa.eu/documents/10180/669262/2014+EU-wide+STaggregate+results.pdf

European Central Bank. (2019). ECB - ROE 2005-2017. Macrotrends (ECB).

European Central Bank. (2019). Banking Supervision Guide. Retrieved from https://www.ecb.europa.eu/pub/pdf/other/ssmguidebankingsupervWoSon201409es.pdf

Fama, E., \& French, K. (2002). The equity premium. The Journal of Finance, 57, 637-659.

Fohlin, C. (1998). Relationship banking, liquidity, and investment in the German industrialization. The Journal of Finance, 53, 1737-1758).

Goddard, J., Molyneux, P., \& Wilson, J. (2004). The profitability of European banks: A crosssectional and dynamic panels analysis. The Manchester School, 72, 363-381.

Hikmet, N., Lin, J., \& Mooney, J. (2011). A path analysis of the determinants of corporate leverage in Japan. Journal of Financial and Economic Practice, 11, 1-8).

INE (National Statistics Institute). Current and constant prices. Retrieved from http://www.ine.es/varipic 
Jobst, A., Ong, L., \& Schmieder, C. (2013, March). A framework for macroprudential bank solvency stress testing: Application to S-25 and other G-20 country FSAPs (Working Paper No. 13/68). International Monetary Fund.

Jérômy, H., \& Kok, C. (2013). A macro stress testing framework for assessing systemic risks in the banking sector. ECB Occasional Paper Series, 152, 29-69.

Kang, J. K., \& Stulz, R. M. (1996). How different is Japanese corporate finance? An investigation of the information content of new securities uses. Review of Financial Studies, 9, 109-139).

King, M. (2009). The cost of equity for global banks: A CAPM perspective from 1990 to 2009. IBIS Quarterly Review, September, 59-72.

Millán, J. R., \& Fruet-Cardozo, J. V. (2012a). Supervisión bancaria internacional. Una doble visión BIS y EBA [International banking supervision: A double BIS and EBA vision]. Madrid, Spain: Bohodón Ediciones S.L.

Morck, R., \& Nakamura, M. (1999). Banks and corporate control in Japan. The Journal of Finance, 54, 319-339.

Rajan, R., \& Zingales, L. (1995). What do we know about capital structure? Some evidence from international data. The Journal of Finance, 50, 1421-1460.

Rose, P. S. (2002). Commercial bank management (5th ed.). Boston, MA, USA: McGraw Hill/Irwin.

Tamames, R. (1971). Estructura económica de España [Economic structure of Spain]. Guadiana de publicaciones S.L.

Trujillo, A. (2013). What determines the profitability of banks? Evidence from Spain. Accounting \& Finance, 53, 561-586.

World Bank. (2016). The Basel III financial architecture and emerging regulatory developments in macro prudential tools. Retrieved from http://documents.worldbank.org/curated/en/758771468092077473/pdf/701540ESW0P 1230ia0AAA0Basel0MacroP.pdf 